\title{
Inflammatory status in patients with chronic renal failure: The role of PTX3 and pro-inflammatory cytokines
}

\author{
GRAZIA MALAPONTE ${ }^{1}$, MASSIMO LIBRA ${ }^{1}$, YLENIA BEVELACQUA ${ }^{1}$, PAOLA MERITO ${ }^{1}$, \\ PASQUALE FATUZZO $^{2}$, FRANCESCO RAPISARDA ${ }^{2}$, MARIA CRISTINA $^{2}$, GABRIELE NASELLI $^{2}$, \\ FRANCA STIVALA $^{1}$, MARIA C. MAZZARINO ${ }^{1}$ and PIETRO CASTELLINO ${ }^{2}$ \\ Departments of ${ }^{1}$ Biomedical Sciences, ${ }^{2}$ Internal Medicine, University of Catania, Catania, Italy
}

Received May 14, 2007; Accepted June 25, 2007

\begin{abstract}
Increased plasma levels of several acute phase proteins, such as C-reactive protein (CRP), have been documented among different patients with chronic renal failure (CRF). The aim of the present study was to determine whether pentraxin-3 (PTX3) is a reliable marker of inflammation in CRF. Plasma samples and monocytes were taken from 43 patients before and after undergoing haemodialysis (HD), from 45 uraemic patients (UR) without HD treatment and from 25 healthy controls. Plasma and monocyte samples were analyzed by ELISA for levels of PTX3, tumor necrosis factor- $\alpha$ (TNF- $\alpha$ ), interleukin-1ß (IL-1ß) and interleukin-6 (IL-6); all of these protein levels were higher in CRF patients with respect to the controls. After HD, plasma PTX3 and cytokine levels increased. Inter- and intra-individual variations in CRP were observed in HD patients, while PTX3 plasma levels were stable. Release of PTX 3, TNF- $\alpha$, IL- $1 \beta$ and IL- 6 by unstimulated monocytes from patients, before and after HD, was higher with respect to UR patients and controls. After lipopolysaccharide stimulation, all values were higher in patients before HD than those in UR patients, but lower when compared to those in the controls. In contrast, no changes were observed after HD. A significant correlation among plasma PTX3 versus fibrinogen, TNF- $\alpha$ and IL-1ß was observed in HD and UR patients. Collectively, these data suggest that PTX3 protein may represent an additional and stable marker of inflammation in CRF.
\end{abstract}

\section{Introduction}

Chronic inflammation is highly prevalent in patients with chronic renal failure (CRF) $(1,2)$. Several investigations have

Correspondence to: Dr Grazia Malaponte, Department of Biomedical Sciences, University of Catania, Via Androne 83, 95124 Catania, Italy

E-mail: g.malaponte@unict.it

Key words: monocytes, cytokines, pentraxin-3, C-reactive protein, fibrinogen, inflammation demonstrated that chronic inflammation may contribute to morbidity and mortality among dialysis patients $(3,4)$. The reason for the increased risk for chronic inflammation in CRF patients is related to multiple factors, such as the deterioration of renal function in uraemia, increased susceptibility to infection and various abnormalities of the immune system (5-7). In addition to the non-dialysis-related factors, repeated exposure to dialysis treatment leads to leucocyte activation with production of cytokines $(8,9)$. Regarding dialysisrelated cytokine induction such as tumor necrosis factor- $\alpha$ (TNF- $\alpha$ ), interleukin-1ß (IL-1ß) and interleukin-6 (IL-6), their up-regulation and presence in the blood circulation may contribute to chronic inflammation $(10,11)$. Therefore, in uraemia, the inflammatory response is characterized by a local reaction induced by pro-inflammatory cytokines that may be followed by activation of the acute phase proteins, such as C-reactive protein (CRP) and fibrinogen (12-15). In chronic haemodialysis (HD) patients, the repetitive induction of the acute phase response may induce a chronic microinflammatory state, leading to a variety of long-term complications, including malnutrition (16) and cardiovascular diseases (17). Previous studies have estimated the severity of inflammation in the healthy and disease states by use of the CRP protein (18-20). Nevertheless, CRP protein may not reliably measure the degree of inflammatory response since the concentration of CRP may be subject to post-transcriptional regulation (21) and, in addition, its large intra- and inter-individual variability $(22,23)$ limits its clinical relevance. Several studies have shown that many healthy subjects and dialysis patients exhibit normal CRP levels (24-26).

It has been shown that long pentraxin-3 (PTX3) is involved in inflammatory processes (27). PTX3 was the first identified long pentraxin (28). It shares an identical Cterminal pentraxin domain with the classical short pentraxins (CRP and serum amyloid P), but PTX3 has an N-terminal domain that is unique to the long pentraxins (29). Pentraxins are a family of proteins usually characterized by cyclic pentameric structure and are considered to be markers of the acute phase of inflammation (30). Short pentraxin synthesis is transcriptionally regulated principally in hepatocytes under the control of a cascade of cytokines including TNF- $\alpha$, IL-6 and IL- $1 \beta$ originating at the site of pathology $(31,32)$.

PTX3 is not synthesized in the liver, but it is produced at extrahepatic sites of inflammation by several cells, primarily 
by dendritic cells, macrophages, fibroblasts, activated endothelia $(33,34)$, and by other tissues, such as the heart and the kidney (35-37). Its production is induced by inflammatory mediators such as lipopolysaccharide (LPS), IL- $1 \beta$ and TNF- $\alpha$, but not IL-6 $(38,39)$. In humans, PTX3 levels are detectable during severe infections $(40,41)$, chronic infection (42) and degenerative conditions such as acute myocardial infarction (43). The role of PTX3 has not been studied in CRF patients. This study was designed to evaluate the usefulness of PTX3 as an additional and stable marker of inflammation in CRF. To elucidate this issue, we analyzed the PTX3 levels and their correlation with biochemical parameters, CRP, fibrinogen and pro-inflammatory cytokines in CRF.

\section{Materials and methods}

Patient characteristics. A total of 115 patients with chronic renal failure (CRF) from two outpatient dialysis centers and from the Internal Medicine Department at the University of Catania, Catania, Italy, were enrolled in this study. Twentyseven patients were excluded who presented clinical signs of infection (hepatitis B, hepatitis C), malignancy, active immunological diseases, immunosuppressive or immunomodulator and anti-inflammatory drugs; conditions that could influence cytokine release. Diabetic patients were excluded from the present study because diabetes may induce an inflammatory response. A total of 88 patients with CRF were considered in this study. The CRF group included 43 patients on haemodialysis (HD) treatment for $>6$ months and 45 uraemic patients (UR). The original renal diseases in the HD patients included chronic glomerulonephritis in 14 patients, chronic pyelonephritis in 8 , polycystic kidney disease in 3, hypertension in 13 and unknown origin in 5 patients. The UR subjects included 20 patients with chronic glomerulonephritis, 10 with chronic pyelonephritis, and 15 with hypertension. Dialysis was performed three times a week for $12 \mathrm{~h} /$ week (4-h sessions). Haemodialysis treatment was performed using bicarbonate-buffered dialysate and hemophane membranes (Gambro Dialysatorem, Hechingen, Germany) in all patients, and there was no dialyser reuse. Neither bacteria nor pyrogen were detected in the dialysate, as determined by the Limulus amoebocyte lysate assay (LAL) (Kabi vitrum, Munich, Germany). The healthy control group (CON) included 25 volunteers from our medical staff. The clinical and biochemical characteristics of the control group and the CRF patients are described in Table I. All subjects gave informed consent to participate in the study.

Study design. Peripheral blood was collected from HD patients before and after undergoing haemodialysis, from UR patients at baseline nephrology examination and from healthy subjects after overnight fast. Peripheral blood from 18 HD patients was collected every week for 8 consecutive weeks for evaluating inter- and intra-variation in CRP and PTX3 levels. Blood samples were put into ethylenediamine tetraacetic acid (EDTA) pyrogen-free tubes and clot activator tubes for the plasma and the serum were removed, aliquoted and stored at $\sim 80^{\circ} \mathrm{C}$ until analyzed. The plasma was used for the evaluation of PTX3 and cytokines; the serum for other biochemical parameters. Serum albumin, creatinine, total cholesterol, high-density lipoprotein (HDL) cholesterol, and triglycerides were measured by standard techniques using an automatic analyzer. CRP was measured by nephelometric immunoassay (Dade Behring, Marburg, Germany). CRP levels below the detection level threshold were scored as $0.175 \mathrm{mg} / \mathrm{l}$. To evaluate the plasma levels of fibrinogen we used a turbidimetric assay (DiaMed, Morat, Switzerland). Levels of TNF- $\alpha$, IL- 6 , and IL-1ß were determined in duplicate samples with a commercial enzyme-linked immunosorbent assay kit (ELISA) (R\&D Systems, Minneapolis, MN, USA), in accordance with the manufacturer's instructions. The lower limit of detection was $0.05 \mathrm{pg} / \mathrm{ml}$ for TNF- $\alpha$, $0.1 \mathrm{pg} / \mathrm{ml}$ for IL-6 and $0.06 \mathrm{pg} / \mathrm{ml}$ for IL- 13 .

Cell isolation, culture and stimulation of monocytes. Peripheral blood mononuclear cells were isolated by centrifugation as previously described (44). Monocytes were prepared by centrifugation at $500 \mathrm{x} \mathrm{g}$ for $30 \mathrm{~min}$ at room temperature on an isosmotic solution of $46 \%$ Percoll (Pharmacia, Uppsala, Sweden). The cells were aspirated from the interface, washed three times in phosphate-buffered saline (PBS) (Gibco, Life Technologies Inc., Milan, Italy) and re-suspended in RPMI culture medium (Gibco Life Technologies Inc.) containing $1 \%$ fetal calf serum (FCS), $2 \mathrm{mmol} / \mathrm{l} \mathrm{L-glutamine,} 100 \mathrm{IU}$ penicillin and $100 \mu \mathrm{g} / \mathrm{ml}$ streptomycin (Gibco Life Technologies Inc.). Cell viability was estimated by the trypan blue exclusion test to be $\sim 95 \%$. The purity of monocytes was analysed on a FACScan flow cytometer (Becton Dickinson, Milan, Italy) with monoclonal antibodies CD14 and CD11c/CD18 (Becton Dickinson). The estimated purity was $\sim 95 \%$, and $>90 \%$ of monocytes were positive for non-specific acid esterase activity. Monocytes were counted in a Neubauer calibrated chamber, were adjusted to a concentration of $1 \times 10^{6}$ cells $/ \mathrm{ml}$ and were incubated for $20 \mathrm{~h}$ at $37^{\circ} \mathrm{C}$ in a $5 \% \mathrm{CO}_{2} / 95 \%$ air atmosphere, in hydrophobic Petriperm dishes (Heraeus, Hanau, Germany). They were cultured without stimulus for evaluation of the spontaneous production of PTX3 and pro-inflammatory cytokines TNF- $\alpha$, IL- 6 and IL-1ß. The supernatant was collected after the 24-h incubation period and filtered through a filter with 0.2-nm pores (Sigma Chemical Co., St. Louis, MO, USA). It was stored at $-80^{\circ} \mathrm{C}$ prior to the analysis of PTX3 and the cytokines. All reagents used were LPS-free, as determined by the LAL assay.

PTX3 protein. PTX3 was measured using a sandwich enzymelinked immunosorbent assay (ELISA) (42). In brief, 96-well ELISA plates (Nunc, Roskilde, Denmark) were coated with $100 \mathrm{ml}$ of anti-PTX3 monoclonal antibody (mAb) MNB4 in coating buffer (15 mM carbonate buffer, $\mathrm{pH}$ 9.6) and incubated overnight at $4^{\circ} \mathrm{C}$. After incubation, the plates were extensively washed three times with washing buffer (phosphate-buffered saline containing $0.05 \%$ Tween-20), and $300 \mathrm{ml}$ of $5 \%$ dry milk in washing buffer was added to block non-specific binding sites. The plates were incubated for $2 \mathrm{~h}$ at room temperature and then washed 3 times with washing buffer. Purified human recombinant PTX3 standards (50 $\mu \mathrm{l})(75 \mathrm{pg} /$ $\mathrm{ml}$ to $10 \mathrm{ng} / \mathrm{ml}$ ), or unknown plasma samples diluted in RPMI-1640 medium (Seromed, Berlin, Germany) and 2\% bovine serum albumin (Sigma Chemicals) were added in 
Table I. PTX3 plasma levels and biochemical parameters in uraemic and haemodialysis patients.

\begin{tabular}{lccc}
\hline & $\begin{array}{c}\text { Healthy controls } \\
\mathrm{n}=25\end{array}$ & $\begin{array}{c}\text { Uraemic patients } \\
\mathrm{n}=45\end{array}$ & $\begin{array}{c}\text { Haemodialysis patients } \\
\mathrm{n}=43\end{array}$ \\
\hline PTX3 (ng/ml) & $1.03 \pm 0.4^{\mathrm{cf}}$ & $2.34 \pm 1.19$ & $3.03 \pm 1.81$ \\
Patient profile & & & \\
Age (years) & $67.7 \pm 7.9$ & $62.8 \pm 14.54$ & $71.86 \pm 9 \mathrm{~g}$ \\
Gender $(\mathrm{M} / \mathrm{F})$ & $14 / 11$ & $26 / 19$ & $24 / 19$ \\
Months on haemodialysis & - & - & $55.8 \pm 53.6$ \\
BMI $\left(\mathrm{kg} / \mathrm{m}^{2)}\right.$ & $29.12 \pm 4.31^{\text {af }}$ & $3.87 \pm 0.41$ & $23.7 \pm 4.4^{\mathrm{h}}$ \\
Albumin $(\mathrm{g} / \mathrm{dl})$ & $4.16 \pm 0.65^{\mathrm{e}}$ & $1.91 \pm 1.13$ & $3.71 \pm 0.35^{\mathrm{h}}$ \\
Creatinine $(\mathrm{mg} / \mathrm{dl})$ & $1 \pm 0.1^{\mathrm{cf}}$ & $56.54 \pm 41.03$ & $7.59 \pm 1.85^{\mathrm{i}}$ \\
Clearance creatinine & $98 \pm 16^{\mathrm{c}}$ & $187.5 \pm 40.83$ & - \\
Cholesterol $(\mathrm{mg} / \mathrm{dl})$ & $188.68 \pm 26.72$ & $42.42 \pm 13.73$ & $176.6 \pm 36.1$ \\
HDL $(\mathrm{mg} / \mathrm{dl})$ & $57.32 \pm 7.37^{\mathrm{cf}}$ & $143.62 \pm 64.52$ & $36.05 \pm 9.01^{\mathrm{g}}$ \\
Triglycerides $(\mathrm{g} / \mathrm{dl})$ & $161.68 \pm 61.57$ & $167.3 \pm 91.2$ \\
\hline
\end{tabular}

PTX3, pentraxin-3; M, male; F, female; BMI, body mass index; HDL, high-density lipoprotein. Data are presented as the mean \pm SD Statistically significant differences between the controls vs uraemic patients $\left({ }^{\mathrm{a}} \mathrm{p}<0.05,{ }^{\mathrm{b}} \mathrm{p}<0.01,{ }^{\mathrm{c}} \mathrm{p}<0.001\right)$; controls vs dialysis patients $\left({ }^{\mathrm{d}} \mathrm{p}<0.05,{ }^{\mathrm{e}} \mathrm{p}<0.01,{ }^{\mathrm{f}} \mathrm{p}<0.001\right)$; and dialysis vs uraemic patients $\left({ }^{\mathrm{g}} \mathrm{p}<0.05,{ }^{\mathrm{h}} \mathrm{p}<0.01,{ }^{\mathrm{i}} \mathrm{p}<0.001\right)$.

Table II. Inflammation markers and cytokines in uraemic and haemodialysis patients.

\begin{tabular}{lccc}
\hline Inflammatory profile & $\begin{array}{c}\text { Healthy controls } \\
\mathrm{n}=25\end{array}$ & $\begin{array}{c}\text { Uraemic patients } \\
\mathrm{n}=45\end{array}$ & $\begin{array}{c}\text { Haemodialysis patients } \\
\mathrm{n}=43\end{array}$ \\
\hline CRP $(\mathrm{mg} / \mathrm{l})$ & $0.9 \pm 0.3^{\mathrm{af}}$ & $5.33 \pm 7.57$ & $7.75 \pm 6.53^{\mathrm{g}}$ \\
Fibrinogen $(\mathrm{g} / \mathrm{dl})$ & $272.3 \pm 45.7^{\mathrm{cf}}$ & $418.8 \pm 95.89$ & $491.3 \pm 123.7^{\mathrm{g}}$ \\
TNF- $\alpha(\mathrm{pg} / \mathrm{ml})$ & $7.1 \pm 1.9^{\mathrm{bf}}$ & $8.93 \pm 2.38$ & $12.73 \pm 4.89^{\mathrm{h}}$ \\
IL-1B $(\mathrm{pg} / \mathrm{ml})$ & $7.4 \pm 1.5^{\mathrm{cf}}$ & $9.21 \pm 2.35$ & $7.1 \pm 5.07^{\mathrm{i}}$ \\
IL-6 $(\mathrm{pg} / \mathrm{ml})$ & $1.8 \pm 0.9^{\mathrm{cf}}$ & $3.55 \pm 2.01$ & $7 \pm 2.06^{\mathrm{i}}$ \\
\hline
\end{tabular}

CRP, C-reactive protein; TNF- $\alpha$, tumor necrosis factor- $\alpha$; IL-1ß, interleukin- $1 \beta$; and IL-6, interleukin- 6 . Data are presented as the mean \pm SD. Statistically significant differences between controls vs uraemic patients $\left({ }^{\mathrm{a}} \mathrm{p}<0.05,{ }^{\mathrm{b}} \mathrm{p}<0.01,{ }^{\mathrm{c}} \mathrm{p}<0.001\right)$; controls vs dialysis patients $\left({ }^{\mathrm{d}} \mathrm{p}<0.05,{ }^{\mathrm{e}} \mathrm{p}<0.01,{ }^{\mathrm{f}} \mathrm{p}<0.001\right)$; and dialysis vs uraemic patients $\left({ }^{\mathrm{g}} \mathrm{p}<0.05,{ }^{\mathrm{h}} \mathrm{p}<0.01,{ }^{\mathrm{i}} \mathrm{p}<0.001\right)$.

triplicate to each well and incubated for $2 \mathrm{~h}$ at $37^{\circ} \mathrm{C}$. The plates were washed 5 times with washing buffer and $100 \mu \mathrm{l}$ of biotinylated rabbit IgG anti-PTX3 diluted 1:2000 in washing buffer was added. The plates were incubated for $1 \mathrm{~h}$ at $37^{\circ} \mathrm{C}$, and then washed 5 times with $300 \mathrm{ml}$ of washing buffer. Streptavidin horseradish peroxidase $(100 \mu \mathrm{l} /$ well) (Amdex, Copenhagen, Denmark) diluted 1:4000 was subsequently added, and the plates were incubated for $1 \mathrm{~h}$ at room temperature. After incubation, the plates were washed 5 times, and $100 \mathrm{ml}$ of the chromogen substrate ABTS (Kirkegaard and Perry Laboratories, Gaithersburg, MD) was added. Plates were read after $15 \mathrm{~min}$ at $405 \mathrm{~nm}$ in an automatic ELISA reader.

Statistical methods. Statistical analysis was performed using SPSS (version 10, SPSS Inc., Chicago, IL, USA). Values were expressed as the mean \pm standard deviation $(\mathrm{SD})$. The distribution of males and females in UR and HD patients was compared by Chi-square analysis. Differences among groups were assessed by the Student's t-test for normally distributed variables and the Wilcoxon test for non-normally distributed variables. The coefficient of variation $(\mathrm{CV})$ was defined as the standard deviation percentage of the mean. The intraindividual $\mathrm{CV}$ was calculated as the $\mathrm{CV}$ of the 8 weekly samples. The inter-individual CV was calculated as the CV of the 18 mean values for each HD patient. Spearman coefficients were calculated to determine the correlation between PTX3 and the biochemical parameters, inflammatory markers and cytokines. Significance tests were two-sided, and values $\mathrm{p}<0.05$ were considered significant.

\section{Results}

The results of our study show, on the one hand, inflammatory parameters between CRF patients and healthy controls, and, on the other, the changes between UR and HD patients. 
Table III. Correlation among inflammation markers and cytokines in uraemic and haemodialysis patients.

\begin{tabular}{lccccc}
\hline & \multicolumn{5}{c}{ Haemodialysis patients $(\mathrm{r})$} \\
\cline { 2 - 6 } & CRP & Fibrinogen & TNF- $\alpha$ & IL-1B & IL-6 \\
\hline CRP $(\mathrm{mg} / \mathrm{l})$ & - & $0.35(\mathrm{p}<0.0500)$ & $0.34(\mathrm{p}<0.0500)$ & $0.42(\mathrm{p}<0.0100)$ & $0.51(\mathrm{p}<0.001)$ \\
Fibrinogen $(\mathrm{g} / \mathrm{dl})$ & $0.35(\mathrm{p}<0.050)$ & - & $0.55(\mathrm{p}<0.0010)$ & $0.62(\mathrm{p}<0.0001)$ & $0.38(\mathrm{p}<0.010)$ \\
TNF- $\alpha(\mathrm{pg} / \mathrm{ml})$ & $0.34(\mathrm{p}<0.050)$ & $0.55(\mathrm{p}<0.0010)$ & - & $0.73(\mathrm{p}<0.0001)$ & $0.50(\mathrm{p}<0.001)$ \\
IL-1 $(\mathrm{pg} / \mathrm{ml})$ & $0.42(\mathrm{p}<0.010)$ & $0.62(\mathrm{p}<0.0001)$ & $0.73(\mathrm{p}<0.0001)$ & - & $0.55(\mathrm{p}<0.001)$ \\
$\mathrm{IL}-6(\mathrm{pg} / \mathrm{ml})$ & $0.51(\mathrm{p}<0.001)$ & $0.38(\mathrm{p}<0.0100)$ & $0.50(\mathrm{p}<0.0010)$ & $0.55(\mathrm{p}<0.0010)$ & - \\
\hline
\end{tabular}

CRP, C-reactive protein; TNF- $\alpha$, tumor necrosis factor- $\alpha$; IL-1ß, interleukin-1ß; IL-6, interleukin-6; r, Spearman rank correlation.

Table IV. Mean, intra- and inter-individual coefficients of variation for PTX3 and CRP in 18 haemodialysis patients.

\begin{tabular}{lccc}
\hline & Mean & $\begin{array}{c}\text { Intra-individual } \\
\text { CV }\end{array}$ & $\begin{array}{c}\text { Inter-individual } \\
\text { CV }\end{array}$ \\
\hline PTX3 (ng/ml) & $3.03 \pm 1.81$ & 0.01 & 0.23 \\
CRP (mg/l) & $7.75 \pm 6.53$ & 0.22 & 0.69 \\
\hline
\end{tabular}

PTX3, pentraxin-3; CRP, C-reactive protein; CV, coefficient of variation. Data are presented as the mean $\pm \mathrm{SD}$.

Plasma PTX3 levels and clinical features. Plasma PTX3 levels and clinical features of three groups of subjects are shown in Table I. Plasma PTX3 levels were higher in HD and UR patients than in the healthy controls $(\mathrm{CON})(\mathrm{p}<0.001$, $\mathrm{p}<0.001$; respectively). Plasma PTX3 levels from UR patients were lower when compared with those from HD patients, but the difference was not statistically significant. Significant differences in some clinical features such as BMI, albumin, creatinine and HDL-cholesterol were found in HD patients when compared with UR patients and CON. In contrast, total cholesterol and triglyceride levels were not significantly different among all groups. No differences in albumin serum levels were also observed between UR patients and CON (Table I).

CRP, fibrinogen and pro-inflammatory cytokines. Serum CRP, plasma fibrinogen and cytokine (TNF- $\alpha$, IL-6 and IL-1ß) levels were also studied as inflammatory markers (Table II). Among HD patients only 22 of 43 (51.1\%) showed increased serum levels of CRP. This increase was significantly higher in the HD patients than in the UR patients $(\mathrm{p}<0.05)$; in fact, only 13 of $45(28.8 \%)$ had high CRP levels. The mean value of CRP was 4-6 times higher in the HD patients than in the UR patients and CON. Plasma fibrinogen levels were significantly higher in the HD patients than in the UR patients and CON ( $p<0.05, p<0.001$; respectively). In fact, fibrinogen values were $\sim 1.5-2$ times higher in HD patients than in UR patients and CON. Furthermore, fibrinogen levels were also higher in the uraemic group compared to the control group $(\mathrm{p}<0.001)$ (Table II). A similar trend for CRP and fibrinogen was found for plasma TNF- $\alpha$, IL-1ß and IL- 6 cytokines. TNF- $\alpha$,
Table V. Plasma levels of PTX3 and cytokines before and after HD.

\begin{tabular}{lrrr}
\hline & Before HD & After HD & p-value \\
\hline PTX3 $(\mathrm{ng} / \mathrm{ml})$ & $3.03 \pm 1.81$ & $4.82 \pm 2.63$ & $<0.0001$ \\
TNF- $\alpha(\mathrm{pg} / \mathrm{ml})$ & $12.73 \pm 4.89$ & $17.05 \pm 7.65$ & $<0.0001$ \\
IL-1B $(\mathrm{pg} / \mathrm{ml})$ & $18.63 \pm 2.79$ & $23.07 \pm 3.72$ & $<0.0001$ \\
IL-6 $(\mathrm{pg} / \mathrm{ml})$ & $7.00 \pm 2.06$ & $9.57 \pm 2.94$ & $<0.0001$ \\
\hline
\end{tabular}

PTX3, pentraxin-3; TNF- $\alpha$, tumor necrosis factor- $\alpha$; IL-1ß, interleukin-1B; IL-6, interleukin-6. Data are presented as the mean \pm SD.

IL- $1 ß$ and IL- 6 mean levels were significantly higher in HD patients than in UR patients $(\mathrm{p}<0.01, \mathrm{p}<0.001, \mathrm{p}<0.001$; respectively) and $\mathrm{CON}(\mathrm{p}<0.001, \mathrm{p}<0.001, \mathrm{p}<0.001$; respectively). UR patients exhibited significantly higher cytokine levels than CON ( $<<0.01, \mathrm{p}<0.001, \mathrm{p}<0.001$; respectively). In addition, we correlated different inflammatory parameters with each other. As shown in Table III, positive correlations among CRP, fibrinogen, TNF- $\alpha$, IL-1ß and IL-6 were found in HD and UR patients. Similar correlations among different inflammatory parameters were observed in UR patients (data not shown).

Inter- and intra-individual changes in CRP and PTX3 levels of $18 \mathrm{HD}$ patients. Time-dependent changes in CRP were observed in HD patients, whereas PTX3 plasma levels were stable (Fig. 1). The means, inter- and intra-individual CVs for both CRP and PTX3 are provided in Table IV.

Effect of haemodialysis session on plasma PTX3, TNF- $\alpha, I L-1 \beta$ and IL-6 levels. A significant increase in PTX3, TNF- $\alpha, \mathrm{IL}-1 \beta$ and IL-6 plasma levels was observed in HD patients after haemodialysis when compared with those detected before haemodialysis (Table V).

Effect of PTX3 on biochemical parameters, CRP, fibrinogen and pro-inflammatory cytokines. As shown in Table VI, to test the effect of PTX3 on biochemical parameters, CRP, fibrinogen and pro-inflammatory cytokines, we divided patients with CRF in the two groups according to their PTX3 values: PTX3 <2 ng/ml (low PTX3 group) and PTX3 >2 ng/ 


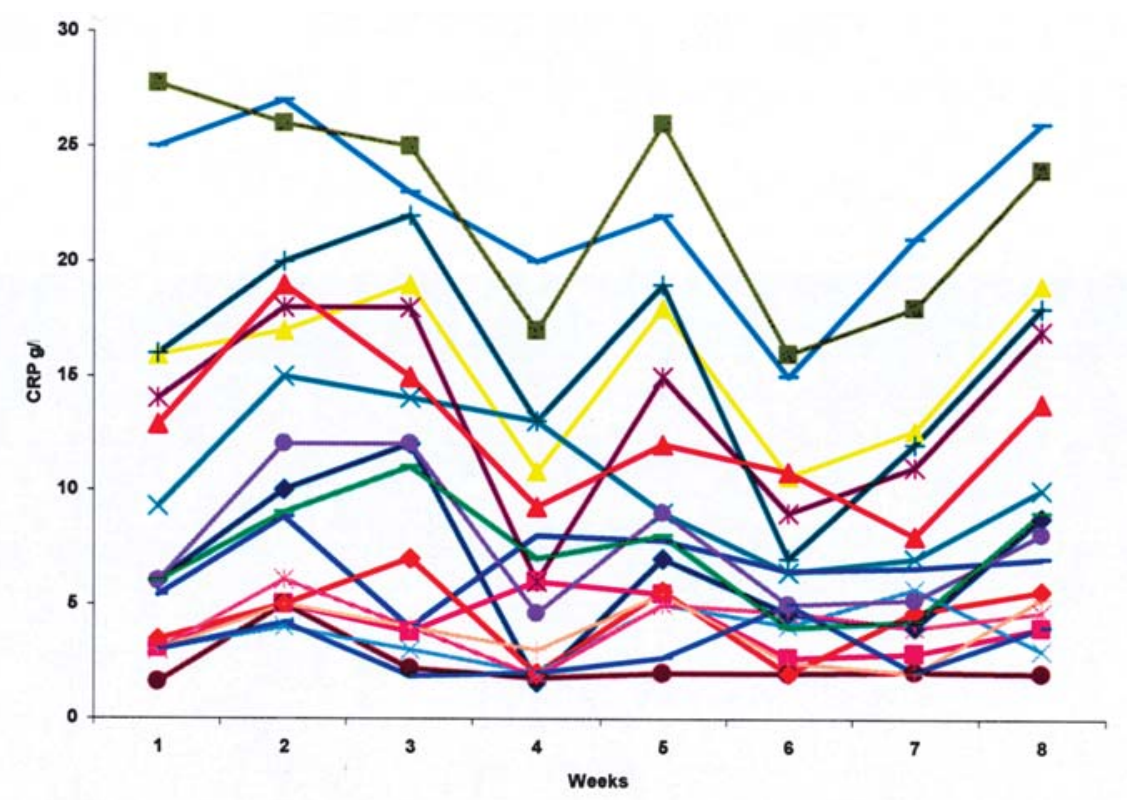

\section{A}

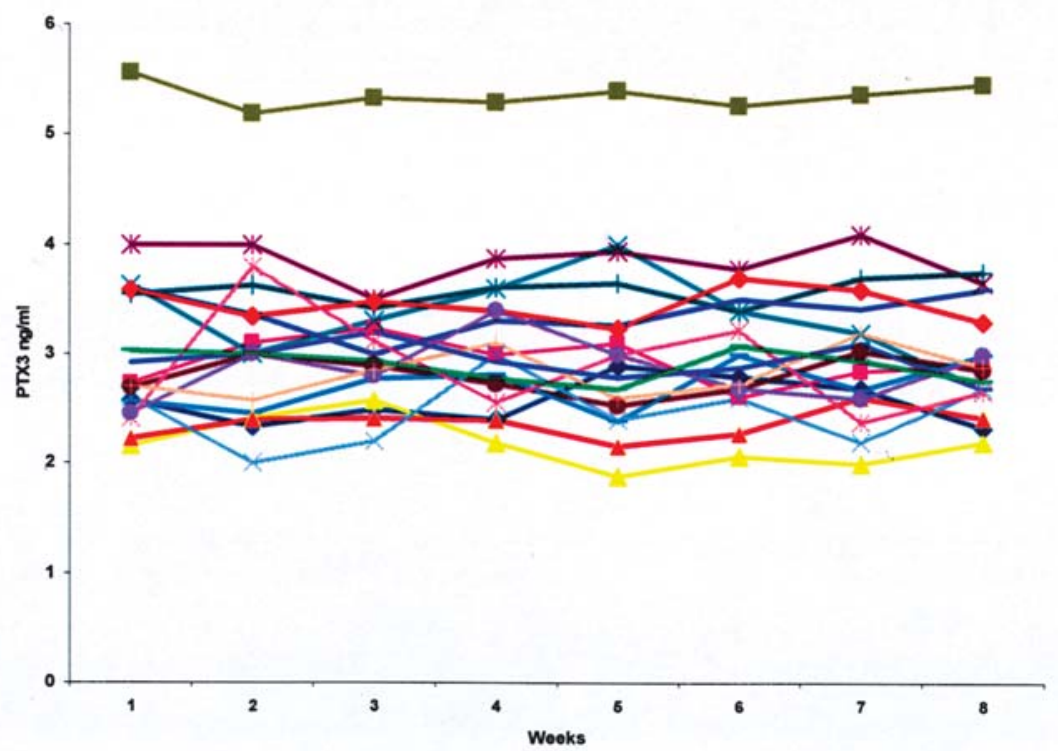

B

Figure 1. Time-dependent changes in CRP (A) and PTX3 (B) levels of 18 HD patients.

ml (high PTX3 group). To determine the PTX3 value (PTX3 $<$ or $>2 \mathrm{ng} / \mathrm{ml}$ ), the patients underwent three PTX3 measurements over 3 months. PTX3 concentrations were found to be elevated $(>2 \mathrm{ng} / \mathrm{ml})$ in 55.8 and $51.1 \%$ of HD and UR patients, respectively.

The mean age was similar in the two groups. BMI and HDL-cholesterol levels were significantly lower in the HD patients with higher PTX3 compared to the low PTX3 group $(\mathrm{p}<0.001, \mathrm{p}<0.05$; respectively). In contrast, in UR patients, no differences were found for BMI and HDL-cholesterol in both groups. There were no differences between the two groups with respect to serum albumin, creatinine, cholesterol, triglyceride and CRP levels. However, in CRF patients, fibrinogen levels were significantly increased in the high
PTX3 group compared to the low PTX3 group. Furthermore, in the high PTX3 group a significant increase in TNF- $\alpha$ and IL-1ß was observed, both in HD $(p<0.001, p<0.001$; respectively) and in UR patients $(\mathrm{p}<0.001, \mathrm{p}<0.001$; respectively), whereas IL-6 levels were not different.

In addition, only in the high PTX3 group, a correlation between the PTX3 levels and the biochemical parameters, inflammatory markers and cytokines was found (Table VII). A negative correlation was observed among BMI and HDLcholesterol with PTX3 levels in HD patients, yet no correlation was demonstrated in UR patients. In CRF patients, no correlation between PTX3 with serum albumin, creatinine, cholesterol, triglycerides and CRP was observed. In contrast, a strong positive correlation was found between 
Table VI. Biochemical parameters, inflammation markers and cytokines in uraemic and haemodialysis patients with low and high plasma levels of PTX3.

\begin{tabular}{|c|c|c|c|c|}
\hline & \multicolumn{2}{|c|}{$\begin{array}{c}\text { Low PTX3 group } \\
\text { PTX3 }<2 \text { ng/ml }\end{array}$} & \multicolumn{2}{|c|}{$\begin{array}{l}\text { High PTX3 group } \\
\text { PTX3 > } 2 \text { ng/ml }\end{array}$} \\
\hline & $\begin{array}{c}\text { Uraemic patients } \\
\mathrm{n}=22\end{array}$ & $\begin{array}{l}\text { Haemodialysis patients } \\
n=19\end{array}$ & $\begin{array}{c}\text { Uraemic patients } \\
n=23\end{array}$ & $\begin{array}{l}\text { Haemodialysis patients } \\
\mathrm{n}=24\end{array}$ \\
\hline PTX3 (ng/ml) & $1.3 \pm 0.4$ & $1.7 \pm 0.4$ & $3.3 \pm 0.8^{f}$ & $4.1 \pm 1.8^{\mathrm{c}}$ \\
\hline Age (years) & $59.9 \pm 13.3$ & $71.7 \pm 9.3$ & $65.6 \pm 15.4$ & $72.0 \pm 8.9$ \\
\hline BMI $\left(\mathrm{kg} / \mathrm{m}^{2}\right)$ & $26.8 \pm 4.3$ & $26.1 \pm 3.9$ & $27.3 \pm 5.2$ & $21.8 \pm 4.0^{\mathrm{c}}$ \\
\hline Albumin (g/dl) & $3.9 \pm 0.4$ & $3.7 \pm 0.4$ & $3.9 \pm 0.4$ & $3.7 \pm 0.3$ \\
\hline Creatinine $(\mathrm{mg} / \mathrm{dl})$ & $1.8 \pm 1.3$ & $7.4 \pm 1.8$ & $2.2 \pm 1.1$ & $7.7 \pm 1.9$ \\
\hline Cholesterol (mg/dl) & $184.1 \pm 43.2$ & $181.4 \pm 40.2$ & $190.7 \pm 39.2$ & $172.8 \pm 32.8$ \\
\hline $\operatorname{HDL}(\mathrm{mg} / \mathrm{dl})$ & $44.5 \pm 13.8$ & $40.0 \pm 10.1$ & $40.4 \pm 13.7$ & $33.0 \pm 6.9^{\mathrm{a}}$ \\
\hline Triglycerides (g/dl) & $146.6 \pm 70.4$ & $177.7 \pm 91.9$ & $140.8 \pm 59.8$ & $162.3 \pm 91.8$ \\
\hline CRP (mg/l) & $5.7 \pm 9.6$ & $6.6 \pm 4.9$ & $5.0 \pm 5.1$ & $8.7 \pm 7.5$ \\
\hline Fibrinogen (g/dl) & $373.8 \pm 64.5$ & $409.3 \pm 86.2$ & $461.9 \pm 102.3^{\mathrm{e}}$ & $556.3 \pm 110.2^{\mathrm{c}}$ \\
\hline $\mathrm{TNF}-\alpha(\mathrm{pg} / \mathrm{ml})$ & $7.8 \pm 2.1$ & $9.4 \pm 3.7$ & $10.0 \pm 2.2^{\mathrm{f}}$ & $15.4 \pm 4.0^{\mathrm{c}}$ \\
\hline $\mathrm{IL}-1 ß(\mathrm{pg} / \mathrm{ml})$ & $8.0 \pm 2.1$ & $13.4 \pm 5.1$ & $10.4 \pm 1.9^{\mathrm{f}}$ & $20.1 \pm 2.4^{\mathrm{c}}$ \\
\hline $\mathrm{IL}-6(\mathrm{pg} / \mathrm{ml})$ & $3.4 \pm 2.3$ & $6.5 \pm 1.5$ & $3.7 \pm 1.8$ & $7.4 \pm 2.4$ \\
\hline
\end{tabular}

PTX3, pentraxin-3; BMI, body mass index; HDL, high-density lipoprotein; CRP, C-reactive protein; TNF- $\alpha$, tumor necrosis factor- $\alpha$; IL-1 3 , interleukin-1B; IL-6, interleukin-6. Data are presented as the mean \pm SD. Statistically significant differences between the high PTX3 group versus the low PTX3 group in the haemodialysed patients $\left({ }^{a} \mathrm{P}<0.05,{ }^{\mathrm{b}} \mathrm{p}<0.01,{ }^{\mathrm{c}} \mathrm{p}<0.001\right)$ and differences between the high PTX3 group versus the low PTX3 group in uraemic patients $\left({ }^{\mathrm{d}} \mathrm{p}<0.05,{ }^{\mathrm{e}} \mathrm{p}<0.01,{ }_{\mathrm{p}}^{\mathrm{f}}<0.001\right)$.

Table VII. Correlation between plasma PTX3 levels (high PTX3 group) versus biochemical parameters, inflammation markers and cytokines in uraemic and haemodialysis patients.

\begin{tabular}{lcc}
\hline & $\begin{array}{c}\text { Uraemic } \\
\text { patients }(\mathrm{r})\end{array}$ & $\begin{array}{c}\text { Haemodialysis } \\
\text { patients }(\mathrm{r})\end{array}$ \\
\hline PTX3 plasma versus: & & \\
Age & $\mathrm{NS}$ & $\mathrm{NS}$ \\
BMI $\left(\mathrm{kg} / \mathrm{m}^{2}\right)$ & $\mathrm{NS}$ & $-0.43(\mathrm{p}<0.05)$ \\
Albumin $(\mathrm{g} / \mathrm{dl})$ & $\mathrm{NS}$ & $\mathrm{NS}$ \\
Creatinine $(\mathrm{mg} / \mathrm{dl})$ & $\mathrm{NS}$ & $\mathrm{NS}$ \\
Cholesterol $(\mathrm{mg} / \mathrm{dl})$ & $\mathrm{NS}$ & $\mathrm{NS}$ \\
HDL $(\mathrm{mg} / \mathrm{dl})$ & $\mathrm{NS}$ & $-0.46(\mathrm{p}<0.05)$ \\
Triglycerides $(\mathrm{g} / \mathrm{dl})$ & $\mathrm{NS}$ & $\mathrm{NS}$ \\
CRP $(\mathrm{mg} / \mathrm{l})$ & $\mathrm{NS}$ & $\mathrm{NS}$ \\
Fibrinogen $(\mathrm{g} / \mathrm{dl})$ & $0.53(\mathrm{p}<0.0010)$ & $0.78(\mathrm{p}<0.0001)$ \\
TNF- $\alpha(\mathrm{pg} / \mathrm{ml})$ & $0.71(\mathrm{p}<0.0001)$ & $0.75(\mathrm{p}<0.0001)$ \\
IL-1ß $(\mathrm{pg} / \mathrm{ml})$ & $0.44(\mathrm{p}<0.0500)$ & $0.67(\mathrm{p}<0.0001)$ \\
IL-6 $(\mathrm{pg} / \mathrm{ml})$ & $\mathrm{NS}$ & $\mathrm{NS}$ \\
\hline
\end{tabular}

PTX3, pentraxin-3; CRP, C-reactive protein; TNF- $\alpha$, tumor necrosis factor- $\alpha$; IL-1ß, interleukin-1ß; IL-6, interleukin-6; NS, not significant; r, Spearman rank correlation.

PTX3 and fibrinogen, TNF- $\alpha$ and IL-1ß, but not with IL-6, in all CRF patients. In the low PTX3 group, no correlation was found for the biochemical parameters, inflammatory markers and cytokines (data not shown).
Production of PTX3 by purified monocytes. Fig. 2 shows the production of PTX3 by unstimulated and LPS-stimulated cells. Production of PTX3 by unstimulated monocytes was significantly increased in HD patients compared to UR patients $(\mathrm{p}<0.05)$ and healthy controls $(\mathrm{p}<0.001)$. LPS significantly increased the production of PTX3 in all groups. In particular, monocytes from healthy controls produced significantly more PTX3 than monocytes from HD and UR patients $(\mathrm{p}<0.01, \mathrm{p}<0.001$; respectively) when stimulated with LPS. HD patients showed a slight increase in PTX3 compared to the UR patients $(\mathrm{p}<0.05)$ after LPS stimulation. After haemodialysis, a significant increase in PTX3, secreted by unstimulated monocytes, was observed in patients compared to those before dialysis $(\mathrm{p}<0.001)$; treatment with LPS in monocytes did not induce any change in PTX3 release between pre- and post-HD.

Moreover, we investigated if PTX3 production by monocytes was correlated with PTX3 plasma levels. We found that PTX3 production by both treated and untreated monocytes with LPS was strongly correlated with PTX3 plasma levels $(\mathrm{r}=0.5607, \mathrm{p}<0.0002, \mathrm{r}=0.5039, \mathrm{p} \leq 0.001$; respectively).

Production of TNF- $\alpha, I L-1 \beta$ and IL-6 by purified monocytes. Fig. 3 shows the production of TNF- $\alpha$ (A), IL-1ß (B) and IL-6 (C) by unstimulated and LPS-stimulated monocytes. The production of TNF- $\alpha$, IL- $1 \beta$ and IL- 6 by unstimulated monocytes was significantly higher in $\operatorname{HD}(\mathrm{p}<0.001, \mathrm{p}<0.001$, $\mathrm{p}<0.001$; respectively) and in UR patients $(\mathrm{p}<0.01, \mathrm{p}<0.001$, $\mathrm{p}<0.001$; respectively) compared to healthy controls. Moreover, cytokine concentrations were significantly higher in HD than in UR patients $(\mathrm{p}<0.001, \mathrm{p}<0.001, \mathrm{p}<0.001$; 


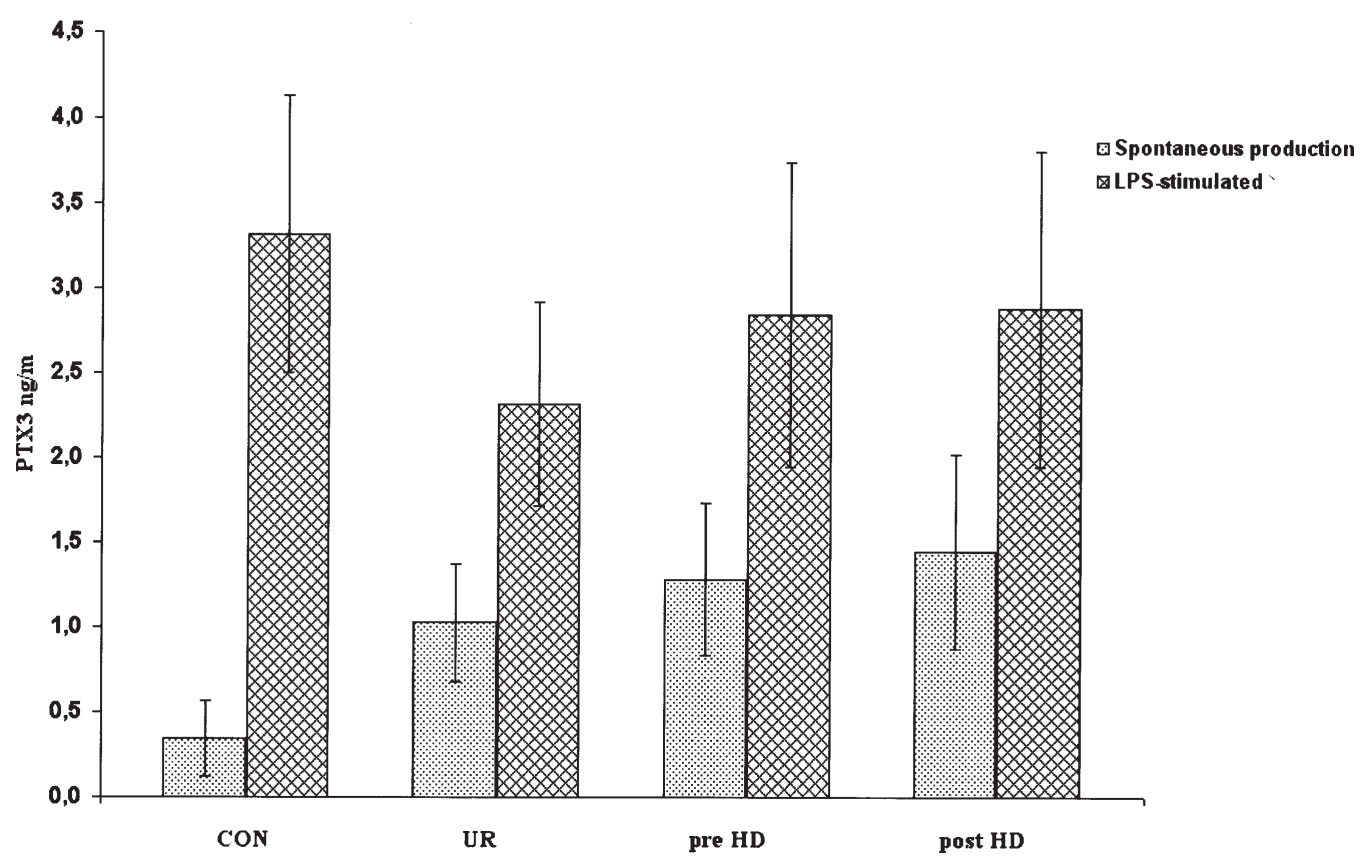

Figure 2. Levels of PTX3 released into the culture supernatant of purified monocytes, with or without stimulation by LPS. Monocytes were prepared from the blood of healthy subjects $(\mathrm{CON}), \mathrm{UR}$ and HD patients pre- and post-dialysis. The results are shown as the means \pm SD.

respectively). In contrast, monocytes from HD and UR patients, when stimulated with LPS, produced less TNF- $\alpha$, IL-1ß and IL-6 ( $<<0.01, p<0.001, p<0.001 ; p<0.01, p<0.01$, $\mathrm{p}<0.001$; respectively) than healthy controls; but the production of cytokines in the HD group was higher than in UR patients $(\mathrm{p}<0.01, \mathrm{p}<0.05, \mathrm{p}<0.01$; respectively). Fig. 3 also shows the production of cytokines during the dialysis session. A significant increase in TNF- $\alpha$, IL- $1 \beta$ and IL-6 in the supernatant of unstimulated monocytes was revealed at the end of dialysis ( $\mathrm{p}<0.001, \mathrm{p}<0.001, \mathrm{p}<0.001$; respectively). LPS stimulation did not induce any change in cytokine concentrations between pre- and post-HD.

\section{Discussion}

The present study was designed to evaluate the usefulness of alternative indices of inflammation. PTX3 is suggested to play an important role in the regulation of inflammatory reactions (27) and in the clearance of apoptotic cells (45). Several authors have indicated CRP as a sensitive marker, but nonspecific of inflammation in various diseases $(46,47)$. However, intra- and inter-individual variability was observed in CRP levels among healthy individuals (23). Given the similarities and differences between PTX3 and CRP (29), we studied PTX3 and its relationship with CRP, fibrinogen, the inflammatory cytokines and biochemical parameters in CRF. To our knowledge, this is the first study analyzing PTX3 levels in HD and UR patients. Here we showed that the spontaneous concentration of PTX3 in the plasma and in the supernatant of unstimulated and LPS-stimulated purified monocytes of HD and UR patients was significantly higher than that of the healthy control group. A strong correlation between plasma PTX3 levels and that secreted in the supernatant from unstimulated and LPS-stimulated purified monocytes adds further weight to our argument.
It has been shown that plasma PTX3 levels are very low in healthy subjects, but are rapidly increased by inflammatory conditions resulting from a wide range of disease states, from infection to autoimmune disorders $(39,40,42,43)$. Inflammatory signals induce the release of PTX3 both in vivo $(40,42,43)$, and in vitro $(34,42)$. Uraemia was found to be associated with deregulation of the inflammatory process and with abnormalities in immune cell reactivity, such as monocytes, which were found to be activated by blood-dialysed membrane interactions (47). This event induces an increased release of pro-inflammatory cytokines, such as TNF- $\alpha$, IL-1ß and IL-6. Since the inflammatory cytokines, as well as microbial components, trigger PTX3 expression in monocytes/ macrophages, endothelial and other cells $(36,39)$, in the present study we analyzed the cytokine release and their relationship to PTX3 in CRF. Similar to previous findings $(44,48-50)$, we found increased cytokine levels in plasma and in the supernatant from monocytes of HD patients compared to UR patients and healthy controls. Similarly, elevated cytokine release was observed in UR patients. As previously described, this increase in cytokine release may be caused by circulating endotoxins in UR (51) and HD patients (52) or non-endotoxemic cytokine-inducing factors $(49,53)$. In contrast to our data, previous studies have shown that cytokine levels were low $(54,55)$ or unmodified $(56,57)$ in HD patients as compared with healthy controls. Therefore, our results indicate that chronic uraemia-related inflammation may be a sufficient signal to stimulate cells producing cytokines in chronic renal patients. Different results for cytokine release from LPS-treated monocytes were observed. In agreement with other studies, the release of TNF- $\alpha$, IL-1B and IL- 6 by LPS-treated monocytes was lower in the HD than in the UR patients and the healthy controls $(44,58)$. These results may be supported by the location of activated monocytes in the lung microvasculature that covers cell 


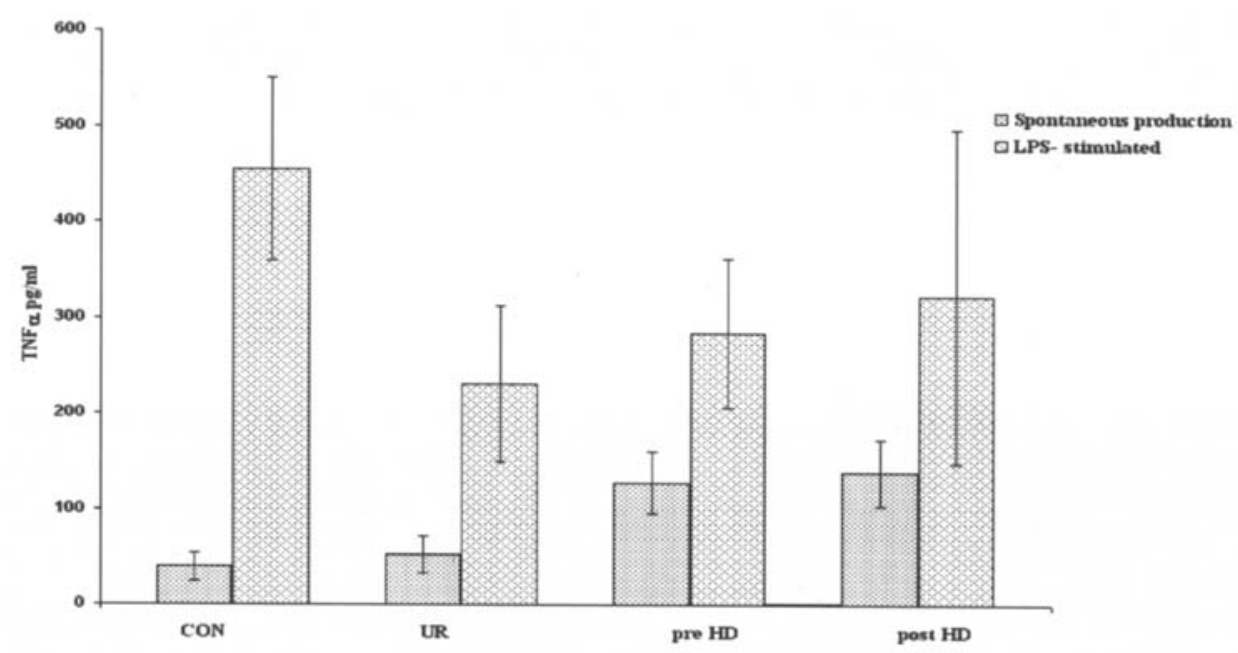

A
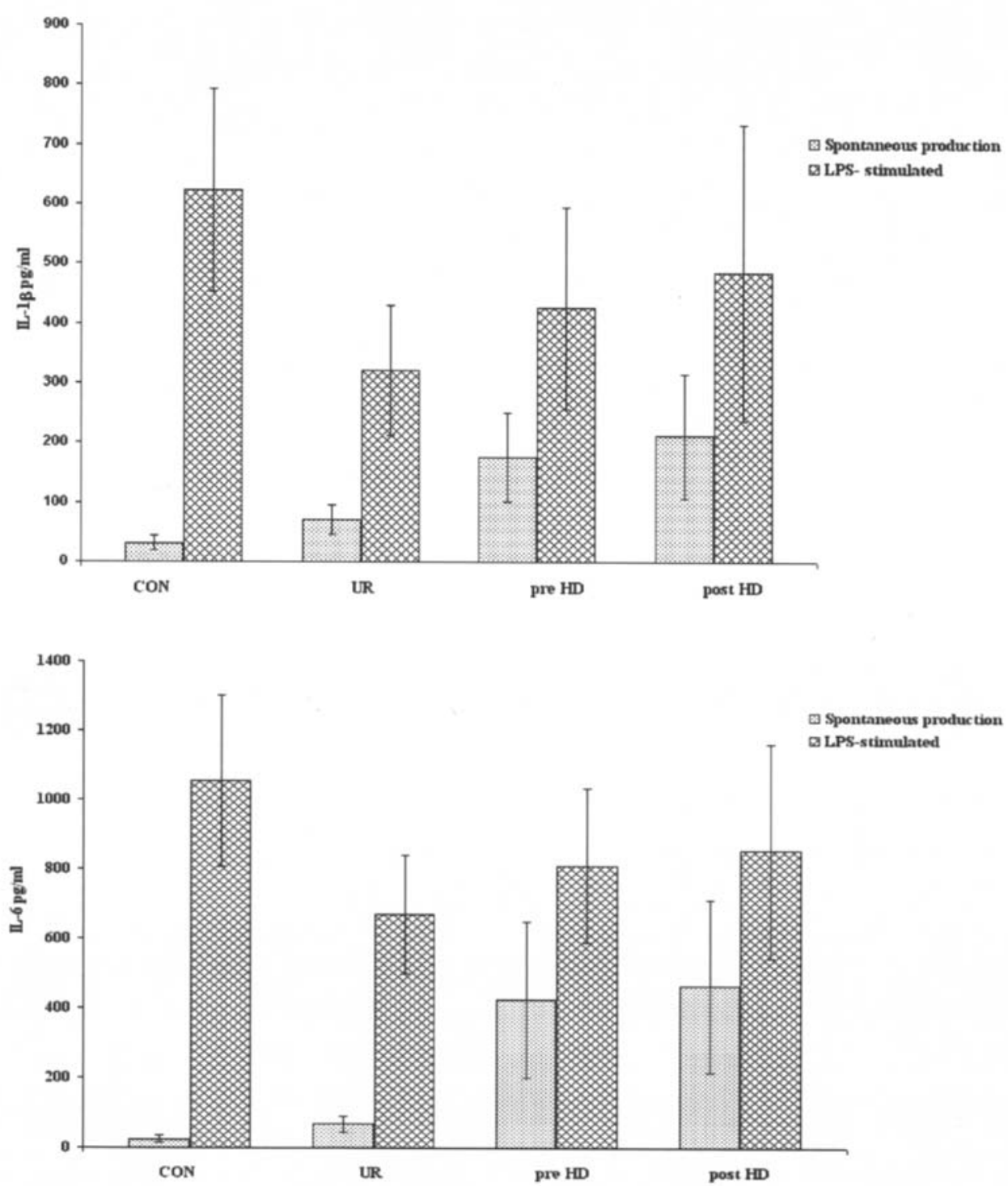

Figure 3. Levels of TNF- $\alpha$ (A), IL-1B (B), and IL-6 (C) released into the culture supernatant of purified monocytes, with or without stimulation by LPS. Monocytes were prepared from the blood of healthy subjects $(\mathrm{CON})$, UR and HD patients pre- and post-dialysis. The results are shown as the means \pm SD.

stimulation during dialysis or by the down-regulation of recurrently activated mononuclear cells to release cytokines, as previously suggested by Zaoui and Hakim (59).

Upon analyzing cytokine levels, a slight yet significant increase, in both the supernatant of unstimulated monocytes and plasma from patients after dialysis compared to those before dialysis was observed. These results are consistent with other studies showing signs of activation of monocytes in HD patients, both ex vivo and in vitro (60-63). In contrast, no change was found in the supernatant of LPS-treated 
monocytes from HD patients; different results were observed by Cassidy et al (64). The interpretation of the role of cytokines in dialysis is complicated by several conflicting factors which include; first, a large degree of interpatient variability in cytokine levels; and second, methodological differences in the collection and processing of specimens, selection of patients and variability in the assay methods employed. In the present study, we utilized purified monocytes obtained by Percoll gradient from chronic renal patients and healthy controls to avoid interference from other cells. Pro-inflammatory cytokines represent a link between PTX3 and acute phase proteins because, on the one hand, cytokines are strong inductors of PTX3 from various cells and, on the other hand, they themselves regulate the acute phase proteins, such as CRP and fibrinogen (65).

Malnutrition and concomitant inflammation in HD patients have been reported (66). Several factors may contribute to these conditions. Malnutrition in HD patients has been proposed to be secondary to inflammation (67). This hypothesis is supported by results of the present study. Since PTX3 is considered an inflammatory marker $(27,30)$, we analyzed the association between both low and high PTX3 levels and some biochemical markers including nutritional parameters in CRF patients. Statistically significant differences between HD and UR patients with high PTX3 levels $(>2 \mathrm{ng} / \mathrm{ml})$ were found in HDL-cholesterol level and BMI. Furthermore, a negative correlation between PTX3 levels and HDL-cholesterol and BMI in HD patients with high PTX3 levels (>2 ng/ml) was observed. Therefore, our findings highlight the association between malnutrition and inflammation throughout the PTX3 analysis.

With respect to biomarkers of inflammation in plasma, the patients with elevated PTX3 values $(>2 \mathrm{ng} / \mathrm{ml})$ showed significantly higher fibrinogen levels, supporting the hypothesis that an inflammatory condition partly contributes to the increased fibrinogen levels in HD and UR patients $(68,69)$. A strong correlation between PTX3 and fibrinogen levels was found among patients with high PTX3 levels. This correlation was observed also in other diseases $(42,70)$. Hyperfibrinogenemia is an important risk factor for atherosclerosis and has been found in HD patients with cardiovascular disease $(71,72)$. PTX3 is also produced by vascular endothelial cells, and it is induced by oxidized LDL in smooth muscle cells (73), implicating a direct pro-inflammatory effect on vasculature (74). PTX3 expression is increased in atherosclerotic lesions (75). Pro-inflammatory cytokines, including TNF- $\alpha$ and IL-1ß, were significantly increased both in HD and in UR patients with high PTX3 levels in comparison with those with low PTX3 levels; while no differences were observed when analyzing for IL-6. PTX3 was positively correlated with both TNF- $\alpha$ and IL- $1 \beta$ in HD and UR patients with high PTX3 levels. Current belief suggests that PTX3 secretion is induced by microbial products and TNF- $\alpha$ and IL- $1 \beta$ cytokines $(30,76)$. TNF- $\alpha$ and IL- $1 \beta$ are mainly produced by macrophages (77). They are released at the site of inflammation, activate endothelial cells and induce CRP production (65). Increased CRP production is induced predominantly by the cytokine IL-6 (32). Although CRP and IL-6 levels were elevated in our HD patients compared to those in the healthy controls, no significant differences were observed between patients with high and low PTX3 levels. In agreement with other studies on CRP and IL-6 in chronic HD patients $(26,78,79)$, we found a strong correlation between TNF- $\alpha$ and IL-1 $\beta$ cytokines (80). Several studies have documented an association between CRP and vascular inflammation $(81,82)$ and atherosclerosis in CRF $(25,83)$. CRP, a PTX3, belongs to the pentraxin family $(28,76)$. Similar to CRP, PTX3 plays an important role in innate immunity $(38,84)$, activates the classical complement pathway and binds apoptotic cells $(45,85-87)$. A pro-atherogenic effect of PTX3 has been documented in endothelial cells (75) and vascular smooth muscle cells $(73,88)$. Although the similarities between PTX3 and CRP have been demonstrated, no correlation between these two inflammatory markers in HD and UR patients was observed in our study. These findings are supported by several observations such as: a) inter- and intra-individual variability in CRP levels (23, present study); b) the much larger range in available values for CRP as well as the much shorter half-lives (20) compared with PTX3 values; c) structural characteristics and the source of production differing between the two proteins (29); d) PTX3 does not bind to be recognized by CRP and SAP ligands (29) and it is not restricted to the liver, such as CRP and SAP, but is expressed in extrahepatic sites, as are the heart, kidney and skeletal muscle (33); and e) PTX3 is produced by monocytes/ macrophages and endothelial cells $(33,76)$.

Our data also showed that PTX3, in contrast to CRP, may be a stable marker because no inter- and intra-variability was observed among HD patients. It has been shown that monocytes/macrophages and endothelial cells play a strong role in CRF (10), inducing inflammatory processes. PTX3 may be a valid candidate to mediate these processes. As suggested by the study of Bottazzi et al, PTX3 plays in tissue the same role that CRP exerts in the circulation (29).

In conclusion, our study provides major insight into defining the PTX3 protein as a novel and stable marker of inflammation. Further studies focusing on the association of PTX3 with intercurrent clinical events in HD are still required.

\section{References}

1. Stenvinkel P: Inflammation in end-stage renal disease - a fire that burns within. Contrib Nephrol 149: 185-199, 2005.

2. Shindler R: Causes and therapy of microinflammation in renal failure. Nephrol Dial Transplant 19 (suppl 5): 34-40, 2004.

3. Ikizler TA, Wingard RL, Harvell J, Shyr Y and Hakim RM: Association of morbidity with markers of nutrition and inflammation in chronic haemodialysis patients: a prospective study. Kidney Int 55: 1945-1951, 1999

4. Chertow GM, Soroko SH, Paganini EP, Cho KC, Himmelfarb J, Ikizler TA and Mehta RL: Mortality after acute renal failure: Models for prognostic stratification and risk adjustment. Kidney Int 70: 1120-1126, 2006.

5. Amore A and Coppo R: Immunological basis of inflammation in dialysis. Nephrol Dial Transplant 17: 16-24, 2002.

6. Descamps-Latscha B, Herbelin A, Nguyen AT, Jungers P and Chatenoud L: Dysregulation of the immune system in chronic uraemic and hemodialysed patients. Presse Med 24: 405-410, 1995.

7. Girndt M, Sester U, Sester M, Kaul H and Kohler H: Impaired cellular immune function in patients with end-stage renal failure. Nephrol Dial Transplant 14: 2807-2810, 1999.

8. Girndt M, Kaul H, Leitnaker CK, Sester M, Sester U and Kohler H: Selective sequestration of cytokine-producing monocytes during haemodialysis treatment. Am J Kidney Dis 37: 954-963, 2001. 
9. Lin YF, Chang DM, Shaio MF, Lu KC, Chyr SH, Li BL and Sheih SD: Cytokine production during haemodialysis: effects of dialytic membrane and complement activation. Am J Nephrol 16: 293-299, 1996.

10. Knerr K, Futh R, Hemsen P, et al: Chronic inflammation and haemodialysis reduce immune competence of peripheral blood leukocytes in end-stage renal failure patients. Cytokine 30: 132-138, 2005

11. Simmons EM, Himmelfarb J, Sezer MT, et al: Plasma cytokine levels predict mortality in patients with acute renal failure. Kidney Int 65: 1357-1365, 2004.

12. Garibotto G, Sofia A, Procopio V, et al: Peripheral tissue release of interleukin-6 in patients with chronic kidney diseases: Effects of end-stage renal disease and microinflammatory state. Kidney Int 70: 384-390, 2006.

13. Stenvinkel P, Ketteler M, Johnson RJ, et al: IL-10, IL-6, and TNF-alpha: central factors in the altered cytokine network of uremia - the good, the bad, and the ugly. Kidney Int 67: 1216-1233, 2005.

14. Lacson E Jr and Levin NW: C-reactive protein and end-stage renal disease. Semin Dial 17: 438-448, 2004.

15. Gabay C and Kushner I: Acute-phase proteins and other systemic responses to inflammation. N Engl J Med 340: 448-454, 1999.

16. Kaysen GA: Inflammation: cause of vascular disease and malnutrition in dialysis patients. Semin Nephrol 24: 431-436, 2004.

17. Lowrie EG: Acute-phase inflammatory process contributes to malnutrition, anemia, and possibly other abnormalities in dialysis patients. Am J Kidney Dis 32 (suppl 4): 105-112, 1998.

18. Stenvinkel P and Lindholm B: C-reactive protein in end-stage renal disease: are there reasons to measure it? Blood Purif 23: 72-78, 2005.

19. Hutchinson WL, Koenig W, Frohlich M, Sund M, Lowe GD and Pepys MB: Immunoradiometric assay of circulating Creactive protein: age-related values in the adult general population. Clin Chem 46: 934-938, 2000.

20. Vigushin DM, Pepys MB and Hawkins PN: Metabolic and scintigraphic studies of radioiodinated human C-reactive protein in health and disease. J Clin Invest 91: 1351-1357, 1993.

21. Kushner I, Jiang SL, Zhang D, Lozanski G and Samols D: Do post-transcriptional mechanisms participate in induction of Creactive protein and serum amyloid A by IL-6 and IL-1? Ann NY Acad Sci 762: 102-107, 1995.

22. Campbell B, Badrick T, Flatman R and Kanowski D: Limited clinical utility of high-sensitivity plasma $\mathrm{C}$-reactive protein assays. Ann Clin Biochem 39: 85-88, 2002.

23. Macy EM, Hayes TE and Tracy RP: Variability in the measurement of C-reactive protein in healthy subjects: implications for reference intervals and epidemiological applications. Clin Chem 43: 52-58, 1997

24. Ledue TB and Rifai N: High sensitivity immunoassays for Creactive protein: promises and pitfalls. Clin Chem Lab Med 39: 1171-1176, 2001

25. Arici $\mathrm{M}$ and Walls J: End-stage renal disease, atherosclerosis, and cardiovascular mortality: is C-reactive protein the missing link? Kidney Int 59: 407-414, 2001.

26. van Tellingen A, Grooteman MP, Schoorl M, et al: Intercurrent clinical events are predictive of plasma C-reactive protein levels in haemodialysis patients. Kidney Int 62: 632-638, 2002.

27. Bottazzi B, Bastone A, Doni A, et al: The long pentraxin PTX3 as a link among innate immunity, inflammation, and female fertility. J Leukoc Biol 79: 909-912, 2006.

28. Goodman AR, Cardozo T, Abagyan R, Altmeyer A, Wisniewski HG and Vilcek J: Long pentraxins: an emerging group of proteins with diverse functions. Cytokine Growth Factor Rev 7: 191-202, 1996.

29. Bottazzi B, Vouret-Craviari V, Bastone A, et al: Multimer formation and ligand recognition by the long pentraxin PTX3. Similarities and differences with the short pentraxins C-reactive protein and serum amyloid P component. J Biol Chem 272: 32817-32823, 1997.

30. Gewurz H, Zhang XH and Lint TF: Structure and function of the pentraxins. Curr Opin Immunol 7: 54-64, 1995.

31. Baumann $\mathrm{H}$ and Gauldie J: The acute phase response. Immunol Today 15: 74-80, 1994.

32. Castell JV, Gomez-Lechon MJ, David M, Fabra R, Trullenque R and Heinrich PC: Acute-phase response of human hepatocytes: regulation of acute-phase protein synthesis by interleukin-6. Hepatology 12: 1179-1186, 1990.

33. Introna M, Alles VV, Castellano M, et al: Cloning of mouse ptx3, a new member of the pentraxin gene family expressed at extrahepatic sites. Blood 87: 1862-1872, 1996.
34. Alles VV, Bottazzi B, Peri G, Golay J, Introna M and Mantovani A: Inducible expression of PTX3, a new member of the pentraxin family, in human mononuclear phagocytes. Blood 84: 3483-3493, 1994

35. Latini R, Maggioni AP, Peri G, et al: Prognostic significance of the long pentraxin PTX3 in acute myocardial infarction. Circulation 110: 2349-2354, 2004.

36. Nauta AJ, de Haij S, Bottazzi B, et al: Human renal epithelial cells produce the long pentraxin PTX3. Kidney Int 67: 543-553, 2005.

37. Bussolati B, Peri G, Salvidio G, Verzola D, Mantovani A and Camussi G: The long pentraxin PTX3 is synthesized in IgA glomerulonephritis and activates mesangial cells. J Immunol 170: 1466-1472, 2003.

38. Mantovani A, Garlanda C and Bottazzi B: Pentraxin 3, a nonredundant soluble pattern recognition receptor involved in innate immunity. Vaccine 21 (suppl 2): 43-47, 2003.

39. Vouret-Craviari V, Matteucci C, Peri G, Poli G, Introna M and Mantovani A: Expression of a long pentraxin, PTX3, by monocytes exposed to the mycobacterial cell wall component lipoarabinomannan. Infect Immun 65: 1345-1350, 1997.

40. Muller B, Peri G, Doni A, Torri V, Landmann R, Bottazzi B and Mantovani A: Circulating levels of the long pentraxin PTX3 correlate with severity of infection in critically ill patients. Crit Care Med 29: 1404-1407, 2001.

41. Rattazzi M, Faggin E, Bertipaglia B and Pauletto P: Innate immunity and atherogenesis. Lupus 14: 747-751, 2005.

42. Bevelacqua V, Libra M, Mazzarino MC, et al: Long pentraxin 3: A marker of inflammation in untreated psoriatic patients. Int $\mathrm{J}$ Mol Med 18: 415-423, 2006.

43. Peri G, Introna M, Corradi D, et al: PTX3, a prototypical long pentraxin, is an early indicator of acute myocardial infarction in humans. Circulation 102: 636-641, 2000.

44. Malaponte G, Bevelacqua V, Fatuzzo P, Rapisarda F, Emmanuele G, Travali S and Mazzarino MC: IL-1beta, TNFalpha and IL-6 release from monocytes in haemodialysis patients in relation to dialytic age. Nephrol Dial Transplant 17: 1964-1970, 2002.

45. Rovere P, Peri G, Fazzini F, Bottazzi B, et al: The long pentraxin PTX3 binds to apoptotic cells and regulates their clearance by antigen-presenting dendritic cells. Blood 96: 4300-4306, 2000.

46. Hirschfield GM and Pepys MB: C-reactive protein and cardiovascular disease: new insights from an old molecule. QJM 96: 793-807, 2003.

47. Vanholder R, Van Haecke E, Veys N and Ringoir S: Endotoxin transfer through dialysis membranes: small- versus large-pore membranes. Nephrol Dial Transplant 7: 333-339, 1992.

48. Girndt M, Kohler H, Schiedhelm-Weick E, Schlaak JF, Meyer zum Buschenfelde KH and Fleischer B: Production of interleukin-6, tumor necrosis factor alpha and interleukin-10 in vitro correlates with the clinical immune defect in chronic haemodialysis patients. Kidney Int 47: 559-565, 1995.

49. Herbelin A, Urena P, Nguyen AT, Zingraff J and Descamps-Latscha B: Influence of first and long-term dialysis on uraemia-associated increased basal production of interleukin-1 and tumour necrosis factor alpha by circulating monocytes. Nephrol Dial Transplant 6: 349-357, 1991

50. Naumovic RT, Djukanovic LD, Ramic ZD and Ostric VZ: Relationship between IL-1beta and TNFalpha production by PBMC and clinical features of haemodialysis patients. Ren Fail 22: 195-204, 2000.

51. Nisbeth U, Hallgren R, Eriksson O and Danielson BG: Endotoxemia in chronic renal failure. Nephron 45: 93-97, 1987.

52. Sundaram S, Barrett TW, Meyer KB, Perrella C, Neto MC, King AJ and Pereira BJ: Transmembrane passage of cytokineinducing bacterial products across new and reprocessed polysulfone dialyzers. J Am Soc Nephrol 7: 2183-2191, 1996.

53. Higuchi T, Fukuda N, Yamamoto C, et al: The influence of uraemic serum on interleukin-1beta and interleukin-1 receptor antagonist production by peripheral blood mononuclear cells. Ther Apher Dial 10: 65-71, 2006.

54. Powell AC, Bland LE, Oettinger CW, McAllister SK, Oliver JC, Arduino MJ and Favero MS: Lack of plasma interleukin-1 beta or tumor necrosis factor-alpha elevation during unfavorable haemodialysis conditions. J Am Soc Nephrol 2: 1007-1013, 1991.

55. Blumenstein M, Schmidt B, Ward RA, et al: Altered interleukin-1 production in patients undergoing haemodialysis. Nephron 50: 277-281, 1988. 
56. Pereira BJ, Poutsiaka DD, King AJ, Strom JA, Narayan G, Levey AS and Dinarello CA: In vitro production of interleukin-1 receptor antagonist in chronic renal failure, CAPD and HD. Kidney Int 42: 1419-1424, 1992.

57. Tarakcioglu M, Erbagci AB, Usalan C, Deveci R and Kocabas R: Acute effect of haemodialysis on serum levels of the proinflammatory cytokines. Mediators Inflamm 12: 15-19, 2003.

58. Friedlander MA, Hilbert CM, Wu YC and Rich EA: Role of dialysis modality in responses of blood monocytes and peritoneal macrophages to endotoxin stimulation. Am J Kidney Dis 22: 11-23, 1993.

59. Zaoui P and Hakim RM: The effects of the dialysis membrane on cytokine release. J Am Soc Nephrol 4: 1711-1718, 1994.

60. Tzanatos HA, Agroyannis B, Chondros C, Kapetanaki A, Fourtounas C, Soubassi L and Kopelias I: Cytokine release and serum lipoprotein (a) alterations during haemodialysis. Artif Organs 24: 329-333, 2000.

61. Guth HJ, Gruska S and Kraatz G: The measurement of cytokine production capacity during dialysis - a new dynamic method for the evaluation of biocompatibility? Int J Artif Organs 23: 675-679, 2000.

62. Mege JL, Olmer M, Purgus R, et al: Haemodialysis membranes modulate chronically the production of TNF alpha, IL1beta and IL6. Nephrol Dial Transplant 6: 868-875, 1991.

63. Varela MP, Kimmel PL, Phillips TM, Mishkin GJ, Lew SQ and Bosch JP: Biocompatibility of haemodialysis membranes: interrelations between plasma complement and cytokine levels. Blood Purif 19: 370-379, 2001.

64. Cassidy MJ, De Jager C, Ebrahim O, Camachio P and Robson S: Peripheral blood mononuclear cells from patients with chronic renal failure release factors which suppress erythropoietin secretion in vitro. Nephrol Dial Transplant 9: 775-779, 1994.

65. Mackiewicz A, Speroff T, Ganapathi MK and Kushner I: Effects of cytokine combinations on acute phase protein production in two human hepatoma cell lines. J Immunol 146: 3032-3037, 1991.

66. Rocco MV, Paranandi L, Burrowes JD, et al: Nutritional status in the HEMO Study cohort at baseline. Haemodialysis. Am J Kidney Dis 39: 245-256, 2002.

67. Kalantar-Zadeh K, Stenvinkel P, Pillon L and Kopple JD: Inflammation and nutrition in renal insufficiency. Adv Ren Replace Ther 10: 155-169, 2003.

68. Kaysen GA, Dubin JA, Muller HG, Mitch WE, Rosales L and Levin NW: HEMO Group: Impact of albumin synthesis rate and the acute phase response in the dual regulation of fibrinogen levels in haemodialysis patients. Kidney Int 63: 315-322, 2003.

69. Giordano M, De Feo P, Lucidi P, et al: Increased albumin and fibrinogen synthesis in haemodialysis patients with normal nutritional status. J Am Soc Nephrol 12: 349-354, 2001.

70. Fazzini F, Peri G, Doni A, et al: PTX3 in small-vessel vasculitides: an independent indicator of disease activity produced at sites of inflammation. Arthritis Rheum 44: 2841-2850, 2001.

71. Irish A: Cardiovascular disease, fibrinogen and the acute phase response: associations with lipids and blood pressure in patients with chronic renal disease. Atherosclerosis 137: 133-139, 1998.
72. Ernst E: Fibrinogen: an important risk factor for atherothrombotic diseases. Ann Med 26: 15-22, 1994.

73. Klouche M, Peri G, Knabbe C, Eckstein HH, Schmid FX, Schmitz G and Mantovani A: Modified atherogenic lipoproteins induce expression of pentraxin-3 by human vascular smooth muscle cells. Atherosclerosis 175: 221-228, 2004.

74. Napoleone E, Di Santo A, Bastone A, et al: Long pentraxin PTX3 upregulates tissue factor expression in human endothelial cells: a novel link between vascular inflammation and clotting activation. Arterioscler Thromb Vasc Biol 22: 782-787, 2002.

75. Rolph MS, Zimmer S, Bottazzi B, et al: Production of the long pentraxin PTX3 in advanced atherosclerotic plaques. Arterioscler Thromb Vasc Biol 22: 10-14, 2002.

76. Lee GW, Goodman AR, Lee TH and Vilcek J: Relationship of TSG-14 protein to the pentraxin family of major acute phase proteins. J Immunol 153: 3700-3707, 1994.

77. Borish LC and Steinke JW: Cytokines and chemokines. J Allergy Clin Immunol 111: S460-S475, 2003.

78. Panichi V, Tetta C, Rindi P, Palla R and Lonnemann G: Plasma $\mathrm{C}$-reactive protein is linked to backfiltration associated interleukin-6 production. ASAIO J 44: M415-M417, 1998.

79. Memoli B, Minutolo R, Bisesti V, et al: Changes of serum albumin and C-reactive protein are related to changes of interleukin-6 release by peripheral blood mononuclear cells in haemodialysis patients treated with different membranes. Am J Kidney Dis 39: 266-273, 2002.

80. Honkanen E, Gronhagen-Riska C, Teppo AM, Maury CP and Meri S: Acute-phase proteins during haemodialysis: correlations with serum interleukin-1beta levels and different dialysis membranes. Nephron 57: 283-287, 1991.

81. Pasceri V, Willerson JT and Yeh ET: Direct proinflammatory effect of C-reactive protein on human endothelial cells. Circulation 102: 2165-2168, 2000.

82. Yeun JY, Levine RA, Mantadilok V and Kaysen GA: C-reactive protein predicts all-cause and cardiovascular mortality in haemodialysis patients. Am J Kidney Dis 35: 469-476, 2000.

83. Lee WY, Allison MA, Kim DJ, Song CH and Barrett-Connor E: Association of interleukin-6 and C-reactive protein with subclinical carotid atherosclerosis (the Rancho Bernardo Study). Am J Cardiol 99: 99-102, 2007.

84. Mortensen RF: C-reactive protein, inflammation, and innate immunity. Immunol Res 24: 163-176, 2001.

85. Nauta AJ, Daha MR, van Kooten C and Roos A: Recognition and clearance of apoptotic cells: a role for complement and pentraxins. Trends Immunol 24: 148-154, 2003.

86. Roumenina LT, Ruseva MM, Zlatarova A, et al: Interaction of $\mathrm{C} 1 \mathrm{q}$ with IgG1, C-reactive protein and pentraxin 3: mutational studies using recombinant globular head modules of human C1q A, B, and C chains. Biochemistry 45: 40093-40104, 2006.

87. Chang MK, Binder CJ, Torzewski $\mathrm{M}$ and Witztum JL: Creactive protein binds to both oxidized LDL and apoptotic cells through recognition of a common ligand: Phosphorylcholine of oxidized phospholipids. Proc Natl Acad Sci USA 99: 13043-13048, 2002.

88. Calabro P, Willerson JT and Yeh ET: Inflammatory cytokines stimulated C-reactive protein production by human coronary artery smooth muscle cells. Circulation 108: 1930-1932, 2003. 